\title{
Increased expression of MMP9 is correlated with poor prognosis of nasopharyngeal carcinoma
}

\author{
Zhen Liư1, Lixia Lit2, Zhixiong Yang², Weiren Luo², Xin Li1 ${ }^{+}$Huiling Yang 3 , Kaitai Yao', Bin Wu*2 and Weiyi Fang*1
}

\begin{abstract}
Introduction: The aim of the present study was to analyze the expression of matrix metalloproteinase 9 (MMP9) in nasopharyngeal carcinoma (NPC) and its correlation with clinicopathologic features, including the survival of patients with NPC.

Methods: Using real-time PCR, we detected the mRNA expression of MMP9 in normal nasopharyngeal tissues and nasopharyngeal carcinoma (NPC) tissues. Using immunohistochemistry analysis, we analyzed MMP9 protein expression in clinicopathologically characterized 164 NPC cases (116 male and 48 female) with age ranging from 17 to 80 years (median $=48.4$ years) and 32 normal nasopharyngeal tissues. Cases with greater than or equal to 6 and less than 6 of the score value of cytoplasmic MMP9 immunostaining were regarded as high expression and low expression, respectively. The relationship between the expression levels of MMP9 and clinical features was analyzed.

Results: The expression level of MMP9 mRNA was markedly greater in NPC tissues than that in the nasopharyngeal tissues. Immunohistochemical analysis revealed that the protein expression of MMP9 detected in NPC tissues was higher than that in the nasopharyngeal tissues $(P=0.004)$. In addition, high levels of MMP9 protein were positively correlated with the status of lymph node metastasis (N classification) $(P=0.002)$ and clinical stage $(P<0.001)$ of NPC patients. Patients with higher MMP9 expression had a significantly shorter overall survival time than did patients with low MMP9 expression. Multivariate analysis suggested that the level of MMP9 expression was an independent prognostic indicator $(P=0.008)$ for the survival of patients with NPC.
\end{abstract}

Conclusion: High level of MMP9 expression is a potential unfavorable prognostic factor for patients with NPC.

\section{Background}

Nasopharyngeal carcinoma (NPC) is one of the most common malignant diseases in the Chinese and other south-east Asians. Unfortunately, most NPC patients tend to present a more advanced stage of disease when first diagnosed due to its deep location and vague symptoms. Therefore, it is of great interest to search valuable factors for early diagnosis, prognosis prediction, and novel therapeutic strategies.

The formation and metastasis of NPC is a complex and continuous process with the participation of a number of key genes [1]. In a previous study, we used cDNA

* Correspondence: wubin1190@126.com, fangweiyi1975@yahoo.com.cn

2 Department of Respiratory Medicine and Cancer Center, Affiliated Hospital of Guangdong Medical College, 524000, Zhanjiang, PR China

${ }^{1}$ Cancer Research Institute, Key Lab for Transcriptomics and Proteomics of Human Fatal Diseases Supported by Ministry of Education and Guangdong Province, Southern Medical University, 510515,Guangzhou, PR China † Contributed equally

Full list of author information is available at the end of the article microarray to detect differentially expressed genes among NPC tissues and non-cancerous nasopharyngeal tissues. By means of the analysis of BRB-array tools, the expression of $M M P 9$, a gene encoding matrix metalloproteinase 9, was shown to be markedly upregulated in NPC tissues, suggesting a possible role of $M M P 9$ in promoting the pathogenesis of NPC [2].

$M M P 9$, a member of the matrix metalloproteinases $(M M P s)$, plays a critical role in breakdown of extracellular matrix in normal physiological processes, such as embryonic development, reproduction, and tissue remodeling, as well as in disease processes, such as tumor metastasis[3]. MMP9 is secreted from cells and, once activated, is thought to degrade collagen in the extracellular matrix, which promotes the metastasis of tumor cells [4].

In order to clarify the role of $M M P 9$ in the pathogenesis of NPC, in the present study we investigated the correlation of $M M P 9$ protein expression with clinicopathologic 
features, including the survival of patients. We found that the mRNA and protein expression levels of $M M P 9$ were higher in NPC tissues than those in non-cancerous nasopharyngeal tissues. Furthermore, the relatively higher protein expression of $M M P 9$ was associated with NPC progression and poor prognosis. Our results suggest that overexpressed $M M P 9$ is an unfavorable prognostic factor for NPC patient's survival.

\section{Materials and methods Sample collection}

Seven primary fresh NPC samples and 5 non-cancerous fresh nasopharyngeal samples were collected from the People's Hospital of Zhongshan City, China, at the time of diagnosis before any therapy. All fresh samples were immediately preserved in liquid nitrogen. One hundred and sixty four undifferentiated NPC specimens and 32 non-cancerous nasopharyngeal specimens, both paraffinembedded, were obtained from the People's Hospital of Zhongshan City and the First Affiliated Hospital of Guangdong Medical School, Zhanjiang City, China. In the 164 NPC cases, there were 116 male and 48 female with age ranging from 17 to 80 years (median, 48.4 years). For the use of these clinical materials for research purposes, prior consents from the patients and approval from the Ethics Committees of these two hospitals were obtained. All specimens had confirmed pathological diagnosis and were staged according to the 1997 NPC staging system of the WHO.

\section{Real-time PCR}

Real-time PCR was performed to measure the expression of MMP9 mRNA in 7 fresh NPC tissues and 5 fresh nasopharyngeal tissues using SYBR Premix Ex Taq (Takara, Japan) with an Mx3000P real-time PCR system (Stratagene, La Jolla, CA, USA) as described previously [5]. The sequence for sense primer was 5'-GAGTGGCAGGGGGAAGATGC-3', and for antisense primer was 5'-CCTCAGGGCACTGCAGGATG-3'. GAPDH gene was used as an internal control using the sense primer 5'-GCACCGTCAAGGCTGAGAAC-3' and antisense primer 5'-TGGTGAAGACGCCAGTGGA-3'.

\section{Immunohistochemistry}

Paraffin sections $(3 \mu \mathrm{m})$ from samples of 164 NPC and 32 nasopharyngeal specimens were deparaffinized in $100 \%$ xylene and re-hydrated in descending ethanol series $(100 \%, 90 \%, 80 \%, 70 \%$ ethanol) and water according to standard protocols. Heat-induced antigen retrieval was performed in $10 \mathrm{mM}$ citrate buffer for $2 \mathrm{~min}$ at $100^{\circ} \mathrm{C}$. Endogenous peroxidase activity and non-specific antigen were blocked with peroxidase blocking reagent containing 3\% hydrogen peroxide and serum, followed by incubation with goat anti-human MMP9 antibody (1:100)
(Abcam, MA, USA) for $1 \mathrm{~h}$ at $37^{\circ} \mathrm{C}$. After washing, the sections were incubated with biotin-labeled rabbit antigoat antibody for $10 \mathrm{~min}$ at room temperature, and subsequently were incubated with streptavidin-conjugated horseradish peroxidase (HRP) (Maixin Inc, China). The peroxidase reaction was developed using 3, 3-diaminobenzidine chromogen solution in DAB buffer substrate. Sections were visualized with DAB and counterstained with hematoxylin, mounted in neutral gum, and analyzed using a bright field microscope.

\section{Evaluation of staining}

The immunohistochemically stained tissue sections were reviewed and scored separately by two pathologists blinded to the clinical parameters. The staining intensity was scored as previously described [6,7]. The extent of the staining, defined as the percentage of positive staining areas of tumor cells or normal nasopharyngeal epithelial cells in relation to the whole tissue area, was scored on a scale of 0 to 4 as the following: $0,<10 \% ; 1,10-25 \% ; 2,26-$ $50 \%$; $3,50-75 \%$; and $4,>76 \%$. The sum of the stainingintensity and staining-extent scores was used as the final staining score for $M M P 9$ (0-7). For statistical analysis, a final staining scores of 0-5 and 6-7 were respectively considered to be low and high expression.

\section{Statistical analyses}

All statistical analyses were performed using SPSS 13.0 software. Data were presented as mean \pm SD. The $X^{2}$ test was used to analyze the relationship between the levels of MMP9 expression and clinicopathologic characteristics. Survival curves were plotted using the Kaplan-Meier method and compared using the log-rank test. The significances of various variables in survival were analyzed using multivariate cox proportional hazards model. A $P$ value of less than 0.05 was considered statistically significant.

\section{Results \\ MMP9 mRNA was highly expressed in NPC tissue}

In order to assess the role of $M M P 9$ in NPC, we performed real-time PCR to measure the expression of $M M P 9$ mRNA transcripts in 7 freshly collected NPC tissues and 5 freshly collected normal nasopharyngeal tissues. Compared with normal nasopharyngeal tissues, NPC tissues showed higher expression levels of MMP9 mRNA with an average increase of 3.4-fold (Figure 1).

\section{Immunohistochemical analysis of MMP9 protein expression} in NPC and nasopharyngeal tissues

We measured the expression levels and subcellular localization of MMP9 protein in 164 archived paraffinembedded NPC samples and 32 non-cancerous nasopharyngeal samples using immunohistochemical staining 


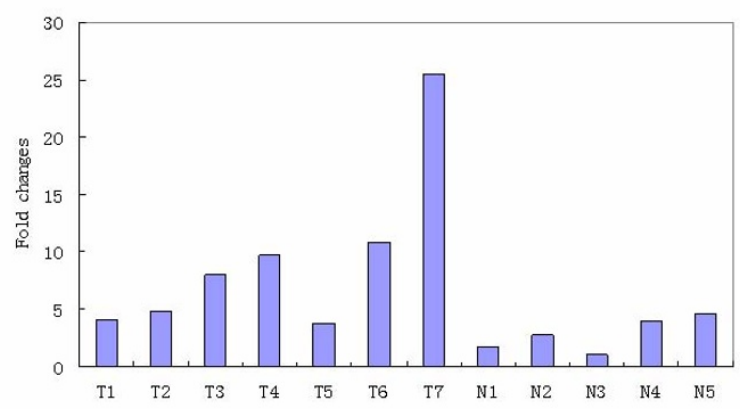

Figure 1 Expression detection of MMP9 mRNA in NPCs and NPs. MMP9 mRNA was highly expressed in NPC tissues compared with NP tissues (3.4 folds).T:Tumor; $\mathbf{N}$ :Normal.

(Figure 2A-E). Specific $M M P 9$ protein staining was found in the cytoplasm of non-cancerous and malignant epithelial cells. Furthermore, we observed that in $77.4 \%$ (127/ 164) of NPC samples, MMP9 protein was highly expressed. In comparison, only $53.1 \%$ of non-cancerous nasopharyngeal samples had highly expressed $M M P 9$ protein, significantly lower than that in the NPC samples $(P=0.008)$ (Table 1$)$.

\section{Relationship between clinicopathological characteristics and MMP9 expression in NPC patients}

The relationships between clinicopathological characteristics and MMP9 expression levels in individuals with NPC are summarized in Table 2. We did not find a significant association of MMP9 expression levels with patient's age, sex, smoking, tumor size (T classification), and status of distant metastasis (M classification) in 164 NPC cases. However, we observed that the expression level of $M M P 9$ was positively correlated with the status of lymph node metastasis (N classification) (N0-N1 vs. N2N3) $(P=0.002)$, and clinical stage (I-II vs. III-IV) $(P<$ 0.000 ) in NPC patients (Table 3).

\section{Survival analysis}

To investigate the prognostic value of $M M P 9$ expression for NPC, we assessed the association between the levels of $M M P 9$ expression and patients' survival using KaplanMeier analysis with the log-rank test. In 164 NPC cases with prognosis information, we observed that the level of $M M P 9$ protein expression was significantly correlated with the overall survival of NPC patients (Figure 2F).
Patients with high level of $M M P 9$ expression had poorer survival than those with lower level of $M M P 9$ expression $(P=0.001)$. In addition, $\mathrm{T}, \mathrm{N}, \mathrm{M}$ classifications and clinical stages were also significantly correlated with patients' survival $(P=0.034, P<0.001, P<0.001$, and $P<0.001$ respectively). To determine whether $M M P 9$ is an independent prognostic factor for NPC, we performed multivariate analysis of the levels of $M M P 9$ protein expression adjusted for age, gender, smoking status, $\mathrm{T}$ classification, $\mathrm{N}$ classification, $\mathrm{M}$ classification, and clinical stages of NPC patients. The results showed that the level of $M M P 9$ expression was an independent prognostic factor for NPC (Table 4).

\section{Discussion}

NPC is a malignant neoplasm arising from the mucosal epithelium of the nasopharynx, most often within the lateral nasopharyngeal recess and has been thought to be closely associated with Epstein-Barr virus infection, dietary, and genetic factors. The majority of the NPC deaths attribute to tumor metastases rather than primary tumors. However, the molecular mechanism of NPC invasion and metastasis remains incompletely understood.

In a recent microarray analysis, we found the significantly elevated level of MMP9 mRNA in NPC compared to non-cancerous nasopharyngeal tissues [2]. In this report, we found that $M M P 9$ was expressed predominantly in the epithelial cells in both NPC and non-cancerous nasopharyngeal tissues by immunohistochemistry assay, which was consistent with Horikawa's result[8]. Similar to a report from Wong et al [9], we further presented the evidence that $M M P 9$ was overexpressed at both mRNA and protein levels in NPC tissues compared to nasopharyngeal tissues, suggesting that $M M P 9$ was involved in the pathogenesis of NPC.

$M M P 9$ is a $\mathrm{Zn}^{2+}$ dependent endopeptidase that mediates the degradation of extracellular matrix protein [10], and is associated with tumor invasion and metastasis $[11,12]$. It is synthesized and secreted in monomeric form as zymogen, and belongs to the gelatinase subgroup. Increased expression of $M M P 9$ is usually seen in invasive and metastatic cancers such as colorectal cancer [13], gastric carcinoma [14], pancreatic carcinoma [15], breast cancer [16], and oral cancer [17]. The levels of MMP9 expression have also been found to be increased in nasal

Table 1: Protein expression of MMP9 between NPC and nasopharyngeal samples

\begin{tabular}{cccc}
\hline Group & Cases & Protein expression & Low expression \\
& & High expression & $37(22.6)$ \\
Cancer & 164 & 127(77.4) & $15(46.9)$ \\
\hline
\end{tabular}




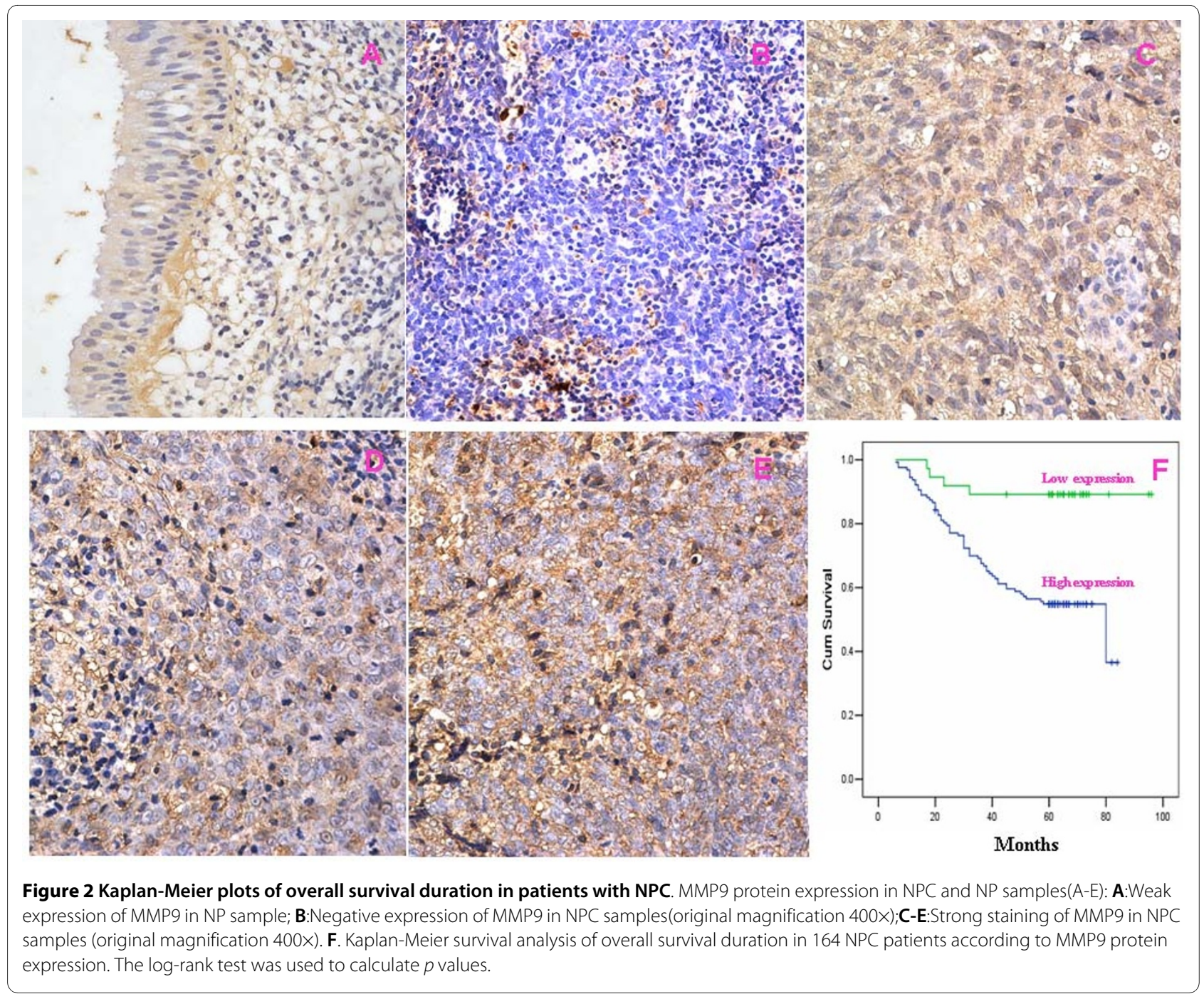

NK/T-cell lymphoma [18], malignant astrocytomas, carcinomatous meningitis, and brain metastases [19]. In this study, we also found that $M M P 9$ overexpression was significantly associated with $\mathrm{T}$ classification (tumor size), $\mathrm{N}$ classification (lymph node metastasis), and clinical stages of NPC patients. Overexpressed MMP9 in NPC may accelerate tumor growth by inducing angiogenesis and enhance local cell invasion and metastasis by degrading the extracellular matrix. Our results may indicate that $M M P 9$ plays significant roles in NPC progression, including tumor invasion and metastasis. Similarly, Horikawa et al also showed that overexpressed MMP9 protein was positively correlated with lymph node metastasis of NPC [8]. Furthermore, the expression of $M M P 9$ also showed a significant positive correlation with the expression of oncoprotein $L M P 1$ in NPC tissues. Transfection of a $L M P 1$ expression plasmid into C33A cell line could increase $M M P 9$ expression [20]. These studies consistently suggest that overexpressed $M M P 9$ may play an unfavorable role in NPC pathogenesis. However, the correlation between $M M P 9$ expression and the survival of NPC patients has been seldom reported.

In the past few years, MMP9 overexpression in tumor cells has been shown to be an independent prognostic factor in several types of tumors, which has a favorable or unfavorable prognostic significance depending on tumor types[21-24]. In epithelial ovarian cancer, the higher the amount of $M M P 9$ positive cancer cells, the longer was the 10-year disease-related survival (DRS) [21]. Interestingly, similar results were reported in breast cancer. Pellikainen found that in breast cancer, positive $M M P 9$ expression in cancer cells favored patient's survival [22]. On the contrary, there was more evidence indicating that overexpression of MMP9 in cancer cells was not a favorable prognosis factor in non-small cell lung cancer(NSCLC) [23], colorectal cancer[24], and oesophageal carcinoma, etc[25]. In NSCLC and colorectal cancer, overexpressed MMP9 was markedly associated with 
Table 2: Clinicopathologic characteristics of patient samples and expression of MMP9 in NPC

\begin{tabular}{|c|c|}
\hline & $\mathbf{N}(\%)$ \\
\hline \multicolumn{2}{|l|}{ Gender } \\
\hline Male & $116(70.7)$ \\
\hline Female & $48(29.3)$ \\
\hline \multicolumn{2}{|l|}{ Age (y) } \\
\hline$<50$ & $83(50.6)$ \\
\hline$\geq 50$ & $81(49.4)$ \\
\hline \multicolumn{2}{|l|}{ Smoking } \\
\hline Yes & $39(23.8)$ \\
\hline No & $125(76.2)$ \\
\hline \multicolumn{2}{|l|}{ T classification } \\
\hline $\mathrm{T}_{1}-\mathrm{T}_{2}$ & $116(70.3)$ \\
\hline $\mathrm{T}_{3}-\mathrm{T}_{4}$ & $48(29.3)$ \\
\hline \multicolumn{2}{|l|}{$\mathrm{N}$ classification } \\
\hline $\mathrm{N}_{0}-\mathrm{N} 1$ & $74(45.1)$ \\
\hline $\mathrm{N}_{2}-\mathrm{N}_{3}$ & $90(54.9)$ \\
\hline \multicolumn{2}{|l|}{ Distant metastasis } \\
\hline Yes & $8(5.1)$ \\
\hline No & $156(94.9)$ \\
\hline \multicolumn{2}{|l|}{ Clinical stage } \\
\hline $\mid \sim \|$ & $55(33.5)$ \\
\hline III IV & $109(66.50)$ \\
\hline \multicolumn{2}{|l|}{ Status at follow-up } \\
\hline Alive & $102(62.2)$ \\
\hline Death secondary to NPC & $62(38.8)$ \\
\hline \multicolumn{2}{|l|}{ Expression of MMP9 } \\
\hline High expression & $127(77.4)$ \\
\hline Low expression & $37(22.6)$ \\
\hline
\end{tabular}

shortened cancer-related survival. In oesophageal carcinoma, MMP9 overexpression was significantly correlated with the depth of tumor invasion, lymphatic permeation, nodal metastasis, and pathologic differentiation grade.

In the present study, we presented the evidence that $M M P 9$ protein expression in NPC was inversely correlated with patient's overall survival. The patients with higher expression of $M M P 9$ protein had shorter survival time. According to multivariate analyses, increased expression of $M M P 9$ protein was a significant predictor of poor prognosis for NPC patients, especially for its patients at late-stage. These results were analogous to $\mathrm{Li}$ et al's report[26] but inconsistent with Wong et al's investigation[9]. Li et al used immunohistochemistry assay in NPC tissues to find that NPC patients with dual highexpression of $M M P 9 / P A R-2$ showed a significantly worse
Table 3: Correlation between the clinicopathologic characteristics and expression of MMP9 protein in NPC

\begin{tabular}{|c|c|c|c|c|}
\hline \multirow[b]{2}{*}{ Characteristics } & \multirow[b]{2}{*}{$\mathbf{n}$} & \multicolumn{2}{|c|}{ MMP9 (\%) } & \multirow[b]{2}{*}{$P$} \\
\hline & & $\begin{array}{c}\text { High } \\
\text { expression }\end{array}$ & $\begin{array}{c}\text { Low } \\
\text { expression }\end{array}$ & \\
\hline \multicolumn{5}{|l|}{ Gender } \\
\hline Male & 116 & $94(81.0)$ & $22(19.0)$ & \\
\hline Female & 48 & $33(43.6)$ & $15(56.4)$ & 0.102 \\
\hline \multicolumn{5}{|l|}{$\operatorname{Age}(y)$} \\
\hline$\geq 50$ & 81 & $61(75.3)$ & $20(24.7)$ & \\
\hline$<50$ & 83 & $66(47.7)$ & $17(52.3)$ & 0.577 \\
\hline \multicolumn{5}{|l|}{ Smoking } \\
\hline Yes & 39 & $31(79.5)$ & $8(20.5)$ & \\
\hline No & 125 & $96(76.8)$ & $29(23.2)$ & 0.828 \\
\hline \multicolumn{5}{|l|}{ T classification } \\
\hline $\mathrm{T}_{1}-\mathrm{T}_{2}$ & 116 & $85(73.3)$ & $31(26.7)$ & \\
\hline $\mathrm{T}_{3}-\mathrm{T}_{4}$ & 48 & $42(87.5)$ & $6(12.5)$ & 0.064 \\
\hline \multicolumn{5}{|l|}{$\mathrm{N}$ classification } \\
\hline $\mathrm{N}_{0}-\mathrm{N}_{1}$ & 74 & $49(66.2)$ & $25(33.8)$ & \\
\hline $\mathrm{N}_{2}-\mathrm{N}_{3}$ & 90 & 78 (86.7) & $12(13.3)$ & 0.002 \\
\hline \multicolumn{5}{|l|}{$\begin{array}{l}\text { Distant } \\
\text { metastasis }\end{array}$} \\
\hline Yes & 8 & $7(87.5)$ & $1(12.5)$ & \\
\hline No & 156 & $120(76.9)$ & $36(23.1)$ & 0.685 \\
\hline \multicolumn{5}{|l|}{ Clinical stage } \\
\hline $\mid \sim \|$ & 55 & $30(54.5)$ & $25(45.5)$ & \\
\hline III IV & 109 & $97(89)$ & $12(11)$ & 0.000 \\
\hline
\end{tabular}

prognosis than those with single highly expressed protein or dual low or negatively expressed proteins, which strongly supported the reliability of our study. However, Wong et al reported that the increased level of plasma pro-MMP 9 by enzyme linked immunosorbant assay did not correlate with NPC patients' clinical outcome. The discrepancy between our data and Wong et al's data would be most likely due to the different samples and method used.

\section{Conclusion}

In summary, our study demonstrated that the expression level of MMP9 was significantly increased in NPC and correlated with the malignant status of NPC. Furthermore, our data suggested that $M M P 9$ was an important prognostic factor for NPC. Yet, due to the limited sample size of patients in our investigation, further studies would be needed to verify these findings and establish the role 
Table 4: Summary of univariate and multivariate Cox regression analysis of overall survival duration

\begin{tabular}{|c|c|c|c|c|c|c|}
\hline \multirow[b]{2}{*}{ Parameter } & \multicolumn{3}{|c|}{ Univariate analysis } & \multicolumn{3}{|c|}{ Multivariate analysis } \\
\hline & $P$ & HR & $95 \% \mathrm{Cl}$ & $P$ & HR & $95 \% \mathrm{Cl}$ \\
\hline \multicolumn{7}{|l|}{ Age } \\
\hline$\geq 50$ vs. $<50$ years & 0.110 & 0.664 & $0.402-1.097$ & 0.038 & 0.556 & $0.320-0.967$ \\
\hline \multicolumn{7}{|l|}{ Gender } \\
\hline Male vs. female & 0.812 & 1.068 & $0.621-1.836$ & 0.868 & 1.050 & $0.588-1.875$ \\
\hline \multicolumn{7}{|l|}{ Smoking } \\
\hline Yes vs. No & 0.538 & 0.836 & $0.473-1.477$ & 0.915 & 0.966 & $0.511-1.826$ \\
\hline \multicolumn{7}{|l|}{ T classification } \\
\hline$T_{1}-T_{2}$ vs. $T_{3}-T_{4}$ & 0.034 & 1.739 & $1.042-2.901$ & 0.191 & 1.519 & $0.812-2.840$ \\
\hline \multicolumn{7}{|l|}{ N classification } \\
\hline $\mathrm{N}_{0}-\mathrm{N} 1$ vs. $\mathrm{N}_{2--} \mathrm{N}_{3}$ & 0.000 & 2.943 & $1.664-5.205$ & 0.018 & 2.849 & $1.197-6.782$ \\
\hline \multicolumn{7}{|l|}{ M classification } \\
\hline$M_{0}$ vs. $M_{1}$ & 0.000 & 0.218 & $0.093-0.509$ & 0.002 & 0.242 & $0.097-0.607$ \\
\hline \multicolumn{7}{|l|}{ Clinical stage } \\
\hline I-II vs. III-IV & 0.000 & 4.323 & $2.055-9.092$ & 0.971 & 1.021 & $0.321-3.251$ \\
\hline \multicolumn{7}{|l|}{ MMP expression } \\
\hline High expression vs. Low expression* & 0.001 & 5.293 & $1.918-14.603$ & 0.003 & 5.193 & $1.728-15.608$ \\
\hline
\end{tabular}

of $M M P 9$ as a reliable clinical predictor for the outcome of NPC patients.

\section{Disclosure of Potential Conflicts of Interest}

No potential conflicts of interest were disclosed

\section{Authors' contributions}

Z.L., B.W., L.L., W.L., X.L. and H.Y. performed this research. Z.L. and W.F. collected, analyzed, and interpreted data and wrote the manuscript. Z.Y. collected and analyzed data. W.F., Z.L., K.Y. and B.W. supervised all the work. All authors have read and approved the final manuscript.

\section{Acknowledgements}

Grants support: National 863 High Technology Research and Development program of China (No.2006AA02A404), United funds of the national natural science foundation and the government of Guangdong Province(u0732006)

\section{Author Details}

${ }^{1}$ Cancer Research Institute, Key Lab for Transcriptomics and Proteomics of Human Fatal Diseases Supported by Ministry of Education and Guangdong Province, Southern Medical University, 510515,Guangzhou, PR China,

2Department of Respiratory Medicine and Cancer Center, Affiliated Hospital of Guangdong Medical College, 524000, Zhanjiang, PR China and Institute of Clinical Medicine, First Affiliated Hospital of University of South China, 421001, Hengyang, PR China

Received: 1 November 2009 Accepted: 9 June 2010

Published: 9 June 2010

\section{References}

1. Cho WC: Nasopharyngeal carcinoma: molecular biomarker discovery and progress. Mol Cancer 2007, 6:1

2. Fang W, Li X, Jiang Q, Liu Z, Yang H, Wang S, Xie S, Liu Q, Liu T, Huang J, et al:: Transcriptional patterns, biomarkers and pathways characterizing nasopharyngeal carcinoma of Southern China. J Trans/ Med 2008, 6:32.
3. Fridman $R$, Toth $M$, Pena $D$, Mobashery S: Activation of progelatinase $B$ (MMP-9) by gelatinase A (MMP-2). Cancer Res 1995, 55(12):2548-2555.

4. Backstrom JR, Tokes ZA: The 84-kDa form of human matrix metalloproteinase-9 degrades substance $P$ and gelatin. J Neurochem 1995, 64(3):1312-1318.

5. Xie SM, Fang WY, Liu Z, Wang SX, Li X, Liu TF, Xie WB, Yao KT: Lentivirusmediated RNAi silencing targeting $A B C C 2$ increasing the sensitivity of a human nasopharyngeal carcinoma cell line against cisplatin. J Trans/ Med 2008, 6:55

6. Wang S, Zhou J, Wang XY, Hao JM, Chen JZ, Zhang XM, Jin H, Liu L, Zhang $Y F$, Liu J, et al.: Down-regulated expression of SATB2 is associated with metastasis and poor prognosis in colorectal cancer. J Pathol 2009, 219(1):114-122

7. Masunaga R, Kohno H, Dhar DK, Ohno S, Shibakita M, Kinugasa S, Yoshimura H, Tachibana M, Kubota H, Nagasue N: Cyclooxygenase-2 expression correlates with tumor neovascularization and prognosis in human colorectal carcinoma patients. Clin Cancer Res 2000, 6(10):4064-4068.

8. Horikawa T, Yoshizaki T, Sheen TS, Lee SY, Furukawa M: Association of latent membrane protein 1 and matrix metalloproteinase 9 with metastasis in nasopharyngeal carcinoma. Cancer 2000, 89(4):715-723.

9. Wong TS, Kwong DL, Sham JS, Wei WI, Kwong YL, Yuen AP: Clinicopathologic significance of plasma matrix metalloproteinase-2 and -9 levels in patients with undifferentiated nasopharyngeal carcinoma. Eur J Surg Oncol 2004, 30(5):560-564.

10. Fridman R, Toth M, Chvyrkova I, Meroueh SO, Mobashery S: Cell surface association of matrix metalloproteinase-9 (gelatinase B). Cancer Metastasis Rev 2003, 22(2-3):153-166.

11. Loesch M, Zhi HY, Hou SW, Qi XM, Li RS, Basir Z, Iftner T, Cuenda A, Chen G: p38\{gamma\} MAPK cooperates with c-Jun in trans-activating matrix metalloproteinase 9. J Bio/ Chem 2010 in press.

12. Lin LF, Chuang CH, Li CF, Liao CC, Cheng CP, Cheng TL, Shen MR, Tseng JT, Chang WC, Lee WH, Wang JM, et al.: ZBRK1 acts as a metastatic suppressor by directly regulating MMP9 in cervical cancer. Cancer Res 2010, 70(1):192-201.

13. Bendardaf R, Buhmeida A, Hilska M, Laato M, Syrjänen S, Syrjänen K, Collan $Y$, Pyrhönen S: MMP-9 (gelatinase B) expression is associated with 
disease-free survival and disease-specific survival in colorectal cancer patients. Cancer Invest 2010, 28(1):38-43.

14. Zhao ZS, Wang YY, Ye ZY, Tao HQ: Prognostic value of tumor-related molecular expression in gastric carcinoma. Pathol Oncol Res 2009, 15(4):589-596.

15. Tian M, Cui YZ, Song GH, Zong MJ, Zhou XY, Chen Y, Han JX: Proteomic analysis identifies MMP-9, DJ-1 and A1BG as overexpressed proteins in pancreatic juice from pancreatic ductal adenocarcinoma patients. BMC Cancer 2008, 8:241.

16. Provatopoulou X, Gounaris A, Kalogera E, Zagouri F, Flessas I, Goussetis E, Nonni A, Papassotiriou I, Zografos G: Circulating levels of matrix metalloproteinase-9 (MMP-9), neutrophil gelatinase-associated lipocalin (NGAL) and their complex MMP-9/NGAL in breast cancer disease. BMC Cancer 2009, 9:390.

17. Patel BP, Shah SV, Shukla SN, Shah PM, Patel PS: Clinical significance of MMP-2 and MMP-9 in patients with oral cancer. Head Neck 2007, 29(6):564-572.

18. Sakata K, Someya M, Omatsu M, Asanuma H, Hasegawa T, Ichimiya S, Hareyama M, Himi T: The enhanced expression of the matrix metalloproteinase 9 in nasal NK/T-cell lymphoma. BMC Cancer 2007, 7:229

19. Friedberg MH, Glantz MJ, Klempner MS, Cole BF, Perides G: Specific matrix metalloproteinase profiles in the cerebrospinal fluid correlated with the presence of malignant astrocytomas, brain metastases, and carcinomatous meningitis. Cancer 1998, 82(5):923-930.

20. Yoshizaki T, Sato H, Furukawa M, Pagano JS: The expression of matrix metalloproteinase 9 is enhanced by Epstein-Barr virus latent membrane protein 1. Proc Natl Acad Sci USA 1998, 95(7):3621-3626.

21. Sillanpaa S, Anttila M, Voutilainen K, Ropponen K, Turpeenniemi-Hujanen T, Puistola U, Tammi R, Tammi M, Sironen R, Saarikoski S, Kosma VM: Prognostic significance of matrix metalloproteinase-9 (MMP-9) in epithelial ovarian cancer. Gynecol Oncol 2007, 104(2):296-303.

22. Pellikainen JM, Ropponen KM, Kataja WV, Kellokoski JK, Eskelinen MJ, Kosma VM: Expression of matrix metalloproteinase (MMP)-2 and MMP9 in breast cancer with a special reference to activator protein-2, HER2, and prognosis. Clin Cancer Res 2004, 10(2):7621-7628.

23. Sienel W, Hellers J, Morresi-Hauf A, Lichtinghagen R, Mutschler W, Jochum M, Klein C, Passlick B, Pantel K: Prognostic impact of matrix metalloproteinase-9 in operable non-small cell lung cancer. Int $\mathrm{J}$ Cancer 2003, 103(5):647-651.

24. Bendardaf R, Buhmeida A, Hilska M, Laato M, Syrjänen S: Cancer Invest.MMP-9 (gelatinase B) expression is associated with disease-free survival and disease-specific survival in colorectal cancer patients. Cancer Invest 2010, 28(1):38-43.

25. Tanioka Y, Yoshida T, Yagawa T, Saiki Y, Takeo S, Harada T, Okazawa T, Yanai $\mathrm{H}$, Okita K: Matrix metalloproteinase-7 and matrix metalloproteinase-9 are associated with unfavourable prognosis in superficial oesophageal cancer. BrJ Cancer 2003, 89(11):2116-2121.

26. Li Z, Bian LJ, Li Y, Liang YJ, Liang HZ: Expression of protease-activated receptor-2 (PAR-2) in patients with nasopharyngeal carcinoma: correlation with clinicopathological features and prognosis. Pathol Res Pract 2009, 205(8):542-550.

Pre-publication history

The pre-publication history for this paper can be accessed here: http://www.biomedcentral.com/1471-2407/10/270/prepub

doi: 10.1186/1471-2407-10-270

Cite this article as: Liu et al., Increased expression of MMP9 is correlated with poor prognosis of nasopharyngeal carcinoma BMC Cancer 2010, 10:270

\section{Submit your next manuscript to BioMed Central and take full advantage of:}

- Convenient online submission

- Thorough peer review

- No space constraints or color figure charges

- Immediate publication on acceptance

- Inclusion in PubMed, CAS, Scopus and Google Scholar

- Research which is freely available for redistribution

Submit your manuscript at www.biomedcentral.com/submit
C Biomed Central 